\title{
AN INSTANCE OF RODENT GEOPHAGY FROM NORTHERN SASKATCHEWAN
}

Frank H. McDougall

134 Haviland Crescent

Saskatoon, SK S7L 5A9

In 2006, I was looking after mining exploration projects in the general area around Points North Landing in northern Saskatchewan.
Points North Landing lies $25 \mathrm{~km}$ west of Wollaston Lake. One day, a member of one of the field crews brought in a piece of rock that he had found while working on one of the mining properties. The rock (Figure 1) bore an odd texture on the surface that he thought was

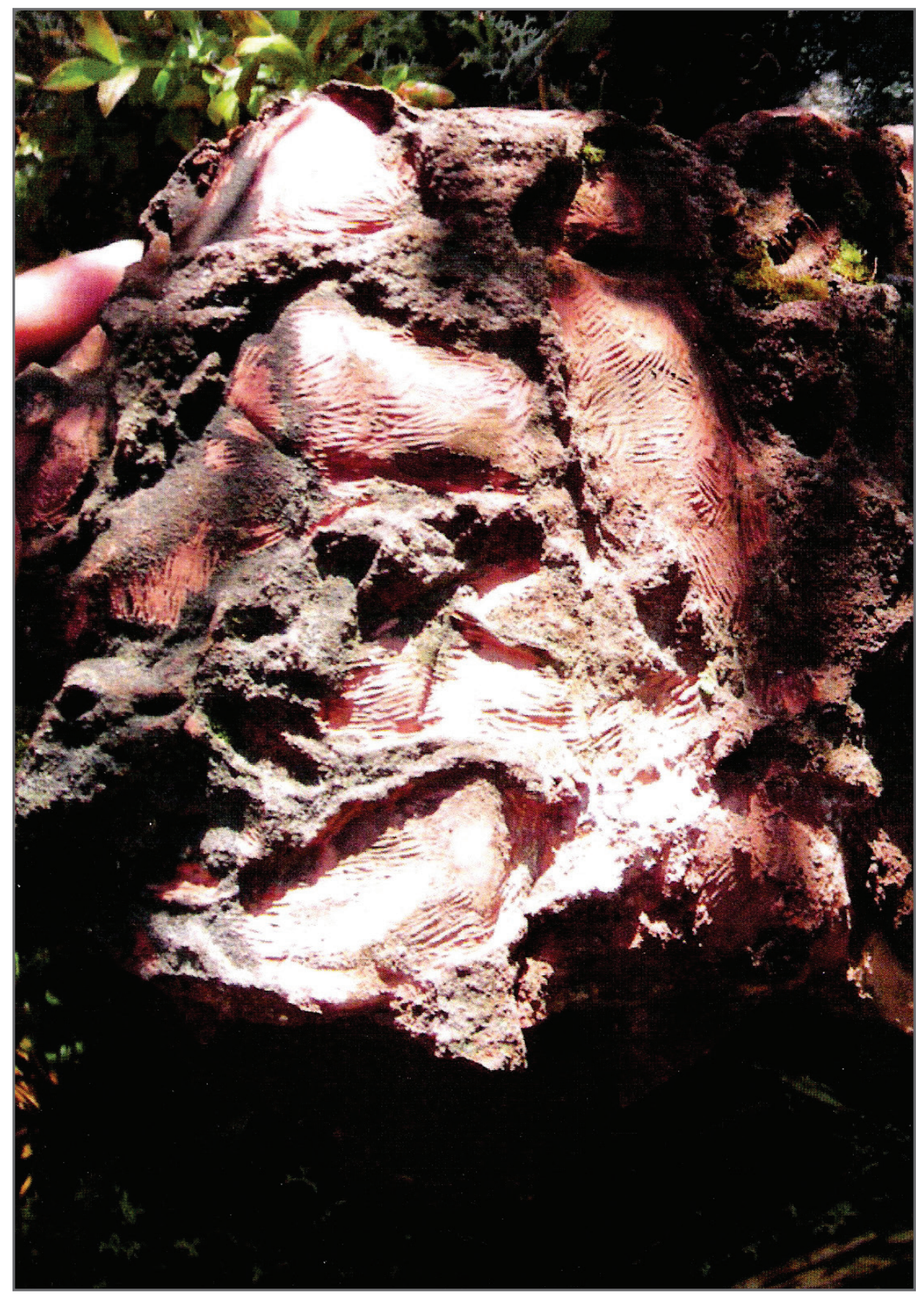

FIGURE 1: Rodent chewed carbonate-rich rock found in the glacial till in the general area of Points North Landing, Saskatchewan. a spinifex texture at first. Spinifex texture is often found in ultramafic volcanic rocks, which are rich in the mineral olivine, and the texture occurs when this mineral forms dendritic plates. Upon examining the specimen, I realized that the surface texture was actually due to rodent chewing. I had seen the same pattern on the surface of deer antlers that had been chewed by rodents that were after minerals like calcium.

Even though the piece of rock had been found in glacial till deposits, I recognized its likely bedrock source area. In 1971, I had worked with the Saskatchewan Geological Survey, as part of a crew mapping the geology of the east half of the Dutton Lake map sheet. This map area lies along the SaskatchewanManitoba border, and extends from 27.5 to $55 \mathrm{~km}$ south of the North West Territories border. The north half of the area that was mapped is underlain by bedrock of the Many Islands Lake belt (Figure 2). This belt of metasedimentary rocks is part of the Precambrian age Hurwitz Group. These rocks contain abundant units of carbonate-rich calc-silicates, and pure carbonate beds that in some cases occur as pure white marble. The carbonates usually weather to a brownish hue with bands of the lessweathered calc-silicates standing out from the surface due to differential weathering. The rock with the rodent chewing was identical to much of the carbonate bedrock exposed in the Dutton Lake map area. The rodent incisor marks are confined to the softer brown and more easily weathered parts of the specimen, while the more resistant silicate rich bands are not affected. Analysis done on 10 samples of the more pure 


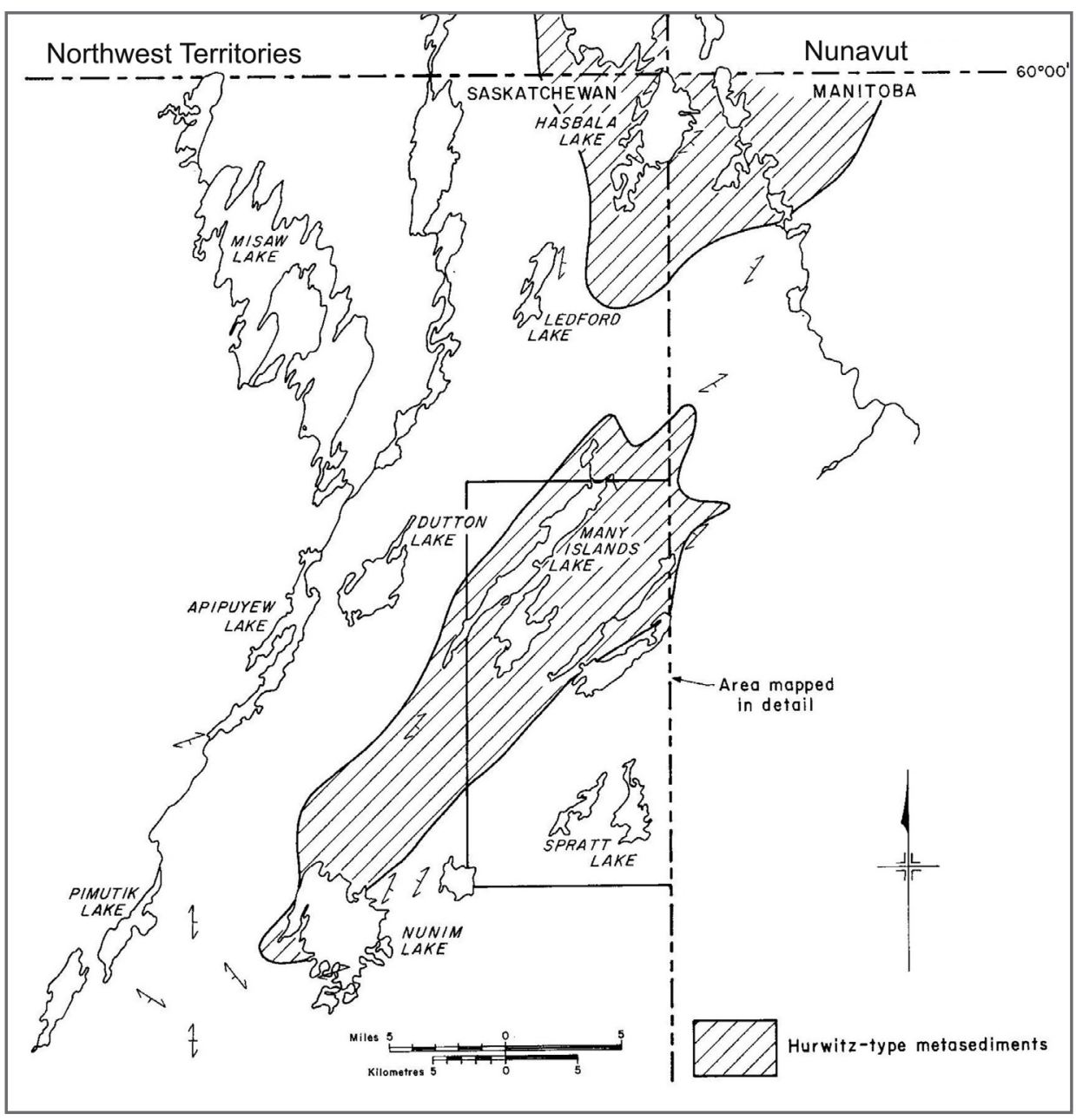

FIGURE 2: Location of Dutton Lake map sheet showing the likely bedrock source of the carbonate rich rock in cross hatched area. Map is modified from previous work on the region. ${ }^{1}$ carbonates (marble) from the 1971 geological survey and presented in the resulting report (\#155) shows their calcium content varies from 8.4 to 16.8 per cent. This is a high content of calcium and is likely the main element that the rodents were acquiring from the rock. Other elements such as iron may also be present in smaller concentrations but a whole rock analysis of the carbonates is not available.

The Dutton Lake area lies 150 $\mathrm{km}$ or more north-northeast of the location where the specimen was found. The direction of Pleistocene glacial ice flow in this area is from north-northeast to south-southwest. This suggests that the location where the chewed rock was found is directly down-ice of the Many Islands Lake belt. As the source area is fairly extensive, it is likely that a considerable amount of these carbonate-rich rocks occur in the down-ice glacial till deposits. ${ }^{1}$ In the area where the bedrock deposits are exposed, the rodents would have an unlimited supply source. However, in the down-ice till deposits, these rocks would form a diminishing source of calcium and other minerals to supplement the rodents' usual dietary sources, such as bones and antlers.

1. Munday RJC (1973) The Geology of the Dutton Lake Area (East Half), Saskatchewan. Saskatchewan Geological Survey, Department of Mineral Resources Report 155:1-22. Accessed March 16, 2020 from https://publications.saskatchewan.ca/\#/ products/7329

\section{POETRY}

\section{Of The Field}

Too hot,

Too windy,

Too many rocks,

Where l'm pounding posts.

And yet,

The most desirable courtesan

In Solomon's palace

Could not smell

So fresh

Could not smell

So sweet

As the Wolf Willow

Where I work. 